\title{
Feeding sorghum stover to Ethiopian sheep and cattle: effect of chopping and amount offered on intake and selection
}

\author{
E. L. K. Osafo', E. Owen², A. N. Said ${ }^{1}$, M. Gill ${ }^{3}$ and A. B. McAllan ${ }^{4}$ \\ IInternational Livestock Centre for Africa, PO Box 5689, Addis Ababa, Ethiopia \\ ${ }^{2}$ Department of Agriculture, Reading University, Reading RG6 2AT \\ ${ }^{3}$ Natural Resources Institute, Chatham Maritime ME4 4TB \\ ${ }^{4} A F R C$ Institute of Grassland and Environmental Research, Hurley, Maidenhead SL6 5LR
}

\section{Introduction}

Offering ad libitum quantities of cereal crop residues which allow animals to select the more nutritious leaf and sheath components and reject the poorer stem has been shown to improve intake in sheep and goats (Wahed, Owen, Naate and Hosking, 1990). The effects of the physical form of sorghum stover offered on intake, have not been explored. There are likely to be differences between sheep and cattle in their selective eating of sorghum stover due to anatomical differences in mouth parts.

Two experiments were conducted to study the intake and selectivity of sheep and cattle offered sorghum stover in varying quantities and form (either chopped or unchopped).

\section{Material and methods}

In experiment 1, $48 \mathrm{Menz}$ highland rams were used over 56 days in a $2 \times 2$ factorial design with four replicate pens each containing three sheep. Factors were amount offered $(25$ or $50 \mathrm{~g} / \mathrm{kg}$ live weight per day) and physical form of stover (chopped or unchopped). Dinkamash (non-bird-resistant) variety was given. Each pen was offered $339 \mathrm{~g}$ dry matter (DM) per day of cottonseed cake supplement. Water and mineral lick were provided. Daily food offered and refusals, per pen, were recorded and samples taken for morphological separation.

Experiment 2 involved 32 individually fed crossbred bulls (zebu $\times$ Friesian) in a $2 \times 2$ factorial design and eight replicates per treatment. Stover variety offered, and treatments, were as in experiment 1 except that cottonseed cake was offered at $790 \mathrm{~g}$ DM per animal per day and duration of the experiment was 49 days.

\section{Results}

Table 1 shows the results of experiment 1 . Intake of stover was significantly increased by both chopping the stover $(P<0.05)$ and offering more $(P<0.001)$. There was no significant $(P>0.05)$ interaction between form and amount of stover offered. Rams selected for leaf and leaf sheath, and against stem (Table 1). The contents $(\mathrm{g} / \mathrm{kg})$ of leaf, leaf sheath and stem respectively in offered stover were: chopped,

Table 1 Results of experiment 1 with rams (per group of three animals)

\begin{tabular}{|c|c|c|c|c|c|c|c|c|}
\hline \multirow{3}{*}{$\begin{array}{l}\text { Amount offered ( } A \text { ) } \\
\text { (g/kg live weight per day) }\end{array}$} & \multicolumn{4}{|c|}{ Form of stover $(F)$} & \multirow[b]{3}{*}{ s.e. } & & & \\
\hline & \multicolumn{2}{|c|}{ Chopped } & \multicolumn{2}{|c|}{ Unchopped } & & \multicolumn{3}{|c|}{ Significance } \\
\hline & 25 & 50 & 25 & 50 & & $\mathbf{F}$ & $\mathbf{A}$ & $\mathbf{F} \times \mathbf{A}$ \\
\hline Live-weight gain (g/day) ${ }^{\circ}$ & $45 \cdot 8$ & 70.5 & 30.5 & 55.9 & $0 \cdot 10$ & *** & $* * *$ & \\
\hline Stover offered (kg DM per day) & 1.23 & $2 \cdot 60$ & 1.25 & 2.56 & $0 \cdot 11$ & & *** & \\
\hline Stover intake (kg DM per day) & 1.08 & 1.60 & 0.98 & $1 \cdot 24$ & 0.08 & * & $* *$ & \\
\hline Leaf intake (kg DM per day) & 0.03 & 0.06 & 0.03 & 0.07 & 0.003 & & $* * *$ & \\
\hline Sheath intake (kg DM per day) & 0.35 & 0.72 & 0.26 & 0.52 & 0.03 & $* *$ & $* * *$ & \\
\hline Stem intake (kg DM per day) & 0.71 & 0.82 & 0.69 & 0.65 & 0.06 & & & \\
\hline Proportion of stover refusal & 0.115 & 0.383 & 0.215 & 0.518 & 0.0310 & $*$ & $* * *$ & \\
\hline
\end{tabular}


Table 2 Results of experiment 2 with bulls (per animal)

\begin{tabular}{|c|c|c|c|c|c|c|c|c|}
\hline \multirow{3}{*}{$\begin{array}{l}\text { Amount offered }(A) \\
\text { (g/kg live weight per day) }\end{array}$} & \multicolumn{4}{|c|}{ Form of stover (F) } & \multirow[b]{3}{*}{ s.e. } & \multirow{2}{*}{\multicolumn{3}{|c|}{ Significance }} \\
\hline & \multicolumn{2}{|c|}{ Chopped } & \multicolumn{2}{|c|}{ Unchopped } & & & & \\
\hline & 25 & 50 & 25 & 50 & & $\mathbf{F}$ & $\mathbf{A}$ & $\mathbf{F} \times \mathbf{A}$ \\
\hline $\begin{array}{l}\text { Stover offered (kg DM per day) } \\
\text { Stover intake (kg DM per day) } \\
\text { Leaf intake (kg DM per day) } \\
\text { Sheath intake (kg DM per day) } \\
\text { Stem intake (kg DM per day) } \\
\text { Proportion of stover refusal }\end{array}$ & $\begin{array}{l}5 \cdot 19 \\
3 \cdot 59 \\
0.46 \\
0.94 \\
2 \cdot 20 \\
0.287\end{array}$ & $\begin{array}{l}9.95 \\
3.94 \\
0.61 \\
1.34 \\
2 \cdot 00 \\
0.597\end{array}$ & $\begin{array}{l}4 \cdot 93 \\
3 \cdot 74 \\
0.46 \\
0 \cdot 87 \\
2 \cdot 42 \\
0.240\end{array}$ & $\begin{array}{l}9.38 \\
4.85 \\
0.76 \\
1.19 \\
2.90 \\
0.486\end{array}$ & $\begin{array}{l}0.20 \\
0.15 \\
0.01 \\
0.03 \\
0.12 \\
0.016\end{array}$ & $\begin{array}{l}* \\
* * \\
* * * \\
* * * \\
* * *\end{array}$ & $\begin{array}{l}* * * \\
* * * \\
* * * \\
* * *\end{array}$ & $\begin{array}{l}* \\
* * * \\
*\end{array}$ \\
\hline
\end{tabular}

24, 284, 693; unchopped, 26, 212, 763. Ram growth rate was significantly increased by both chopping the stover $(P<0.001)$ and offering more $(P<0.001)$.

Table 2 shows the results of experiment 2 . For stover intake, there was a form $X$ amount interaction $(P<0.05)$, indicating that the response to increasing the amount offered was higher with unchopped compared with chopped stover. The cause of the interaction seemed to be the differences in stem intake depending on amount of stover offered (Table 2). The bulls, like the rams, appeared to be selecting for leaf and leaf sheath. The contents $(\mathrm{g} / \mathrm{kg})$ of leaf, leaf sheath and stem respectively in offered stover were: chopped, 108, 207, 685; unchopped, 101, 200, 699.

\section{Discussion}

In sheep, there was an intake-response to both doubling the offer-rate of stover and chopping. There was a greater response to offer-rate than chopping; offer-rate and form did not interact.
In contrast, intake in cattle decreased when stover was chopped and there was a significant form $x$ offer-rate interaction, with the response to increasing the offer-rate being larger with unchopped compared with chopped stover. Both sheep and cattle selected for leaf and sheath fractions.

The experiments indicate that intake of sorghum stover by both sheep and cattle is increased if animals are offered large excesses to facilitate selective feeding. Chopping stover (as in this study) improves intake in sheep, but is detrimental to intake in cattle.

\section{Reference}

Wahed, R. A., Owen, E., Naate, M. and Hosking, B. J. 1990. Feeding straw to small ruminants: effect of amount offered on intake and selection of barley straw by goats and sheep. Animal Production 51: 283-289. 